\title{
Kecerdasaran Suprarasional: Konsep Uli al-Abshâr, Uli an-Nuhâ dan Uli al-Albâb dalam Alquran Perspektif Jalaluddin
}

\author{
Muh. Haris Zubaidillah \\ Dosen, Sekolah Tinggi Ilmu Al-Quran (STIQ) Amuntai, Kalimantan Selatan \\ Email : hariszub@gmail.com
}

\begin{abstract}
Abstrak
Diskusi terkait kecerdasan merupakan topik yang menarik dalam dunia pendidikan, khususnya psikologi pendidikan. Di antara ahli yang berbicara tentang kecerdasan dengan sangat detail dan komprehensif dari sudut pandang psikologi umum dan psikologi pendidikan Islam adalah Jalaluddin. Tujuan kajian ini adalah untuk mendeskripsikan bagaimana konsep Uli al-Abshar, Uli an-Nuha dan Uli al-Albab dalam Alquran perspektif Jalaluddin. Metode yang digunakan adalah metode penelitian kepustakaan dengan teknik analisis isi sebagai prosedur analisisnya. Berdasarkan hasil penelitian dapat disimpulkan kecerdasan yang hakiki menurut Jalaluddin adalah kecerdasan hati, yaitu tingkat kemampuan memahami. Proses penanaman nilai tauhid yang suci sejak awal akan sangat mempengaruhi terhadap produk akal manusia. Proses tersebut akan menghasilkan akal yang cerdas dan hati yang suci. Sinergitas keduanya akan berpengaruh kuat terhadap pembentukan kecerdasan suprarasional. Dalam Alquran konsep kecerdasan manusia selalu dikaitkan dengan nilai-nilai spiritual yang bersumber dari nilai kesucian fitrah yang ada dalam diri manusia. Menurut Jalaluddin, informasi Alquran yang mengacu kepada kecerdasan ini terkandung dalam tiga konsep utama, yakni: Uli al-Abshar, Uli an-Nuha dan Uli al-Albab. Ketiganya dapat dimaknai sebagai orang yang berakal sehat disertai dengan hati yang bersih, selalu dikaitkan dengan nilai-nilai spiritual yang bersumber dari fitrah. Secara teoritis penelitian ini diharapkan dapat berkontribusi dalam menambah khazanah keilmuan dalam disiplin ilmu psikologi khususnya pada tema kecerdasan. Secara praktis penelitian ini diharapkan dapat bermanfaat bagi pelaku pendidikan baik guru maupun orang tua untuk dapat mengembangkan aspek kecerdasan suprarasional anak sebagai prioritas utama guna melahirkan generasi yang memiliki akal yang cerdas dan hati yang bersih sesuai dengan fitrahnya.
\end{abstract}

Kata kunci: kecerdasan, suprarasional, Jalaluddin

\section{A. PENDAHULUAN}

Diskusi terkait kecerdasan merupakan topik yang menarik dalam dunia pendidikan, khususnya psikologi pendidikan. Dalam kajian psikologi pendidikan, beberapa ahli seperti John W. Santrock dalam bukunya Educational Pshycology telah menerangkan dan membahas dengan detail terkait kecerdasan. Begitu juga dalam psikologi pendidikan Islam. Di antara ahli yang berbicara tentang kecerdasan dengan sangat detail dan komprehensif dari sudut pandang psikologi umum dan psikologi pendidikan Islam adalah Prof. Dr. Jalaluddin dalam bukunya yang berjudul Psikologi Pendidikan Islam yang dibahas pada artikel ini.

Dalam buku Psikologi Pendidikan Islam ini, khusus pada sub-bab "Aktivitas pada Tingkat Intelektual Tinggi” Jalaluddin mencoba mengaitkan psikologi pendidikan dengan intelengensia seseorang. ${ }^{1}$

\footnotetext{
${ }^{1}$ Jalaluddin, Psikologi Pendidikan Islam (Yogyakarta: Pustaka Pelajar, 2018), h. 302.
}

Al Qalam: Jurnal Ilmiah Keagamaan dan Kemasyarakatan

Vol. 14, No. 2, Juli-Desember 2020 
Menurutnya psikologi pendidikan tingkah laku yang efisien cenderung dihubungkan dengan intelegensia seseorang. Ia mengutip pendapat H.C. Witherington yang menyatakan bahwa intelegensia adalah kebaikan dari perbuatan atau aktivitas yang efisien. Suatu aktivitas dinyatakan efisien adalah apabila dapat dilakukan dengan cepat, mudah dan akurat. ${ }^{2}$

Otak yang merupakan pusat kecerdasan dianggap sebagai sumber segala aktivitas yang dilakukan oleh manusia. Otak menurut Jalaluddin merupakan organ yang paling kompleks. Hampir semua fungsi raga manusia seperti pikiran, emosi, bicara, detak jantung, kegiatan bernafas hingga dorongan seks, ingatan dan suasana hati, semuanya dikendalikan oleh otak. Oleh karenanya, otak berfungsi sebagai pusat pengendali dan pengordinasi sebagian besar dari gerakan, perilaku dan fungsi homeostatis tubuh. ${ }^{3}$

Secara garis besar, struktur otak besar terbagi menjadi korteks serebri dan struktur-sturktur sub kortikal. Ada korteks sensoris yang berfungsi untuk mengenal, interpretasi dan menyimpan memori, sehingga individu menyadari adanya sensasi rasa. Selain itu di bagian otak besar juga ada juga korteks motoris yang bekerjasama dengan korteks sensoris dalam pemetaan tubuh. Sementara otak kecil berfungsi untuk mengoordinasikan gerakan-gerakan otot sehingga gerakan dapat terlaksana dengan sempurna. ${ }^{4}$

Roger Walcott Sperry membagi otak menjadi otak kanan dan otak kiri. Menurutnya, otak kanan memiliki kemampuan menguasai badan bagian kiri, berfikir rasional, analisis, linier, ilmiah, kemampuan berbahasa, menghitung dan menulis. Bagian ini melahirkan kemampuan verbal. Sementara otak kiri menguasai badan bagian kanan, memimiliki kemampuan berfikir holistis, spasial, kreatif dan motorik. Bagian ini melahirkan kemampuan non-verbal. ${ }^{5}$

Hasil penelitian ilmiah telah membuktikan adanya keragaman fungsi otak yang sangat kompleks dan istimewa itu. Semuanya pengaturan aktivitas tubuh terutama intelegensia, ingatan dan keputusan dikendalikan oleh otak. Namun, pada rentang hasil dimaksud belum terungkap bahwa otak memiliki fungsi yang terkait dengan pemahaman manusia. ${ }^{6}$

Ketika otak (akal) hanya berkutat pada tataran kesadaran, menurut Jaaluddin hati bisa menerobos ke alam ketidaksadaran (alam ghaib dalam bahasa religius) sehingga dapat memahami pengalaman-pengalaman yang non inderawi, termasuk pengalaman mistik dan religius. Hal ini dibuktikan melalui telaah psikologi transpersonal yang menyatakan bahwa potensi luhur dapat mengungkapkan adanya pengalaman manusia melewati batas-batas kesadaran biasa. ${ }^{7}$

Dalam Alquran konsep kecerdasan manusia selalu dikaitkan dengan nilai-nilai spiritual yang bersumber dari nilai kesucian fitrah yang ada dalam diri manusia. Menurut Jalaluddin, informasi Alquran yang mengacu kepada kecerdasan ini terkandung dalam tiga konsep utama, yakni: Uli al-Abshar, Uli anNuha dan Uli al-Albab. Oleh karena itu, dalam artikel ini penulis tertarik untuk menelaah makna Uli alAbshar, Uli an-Nuha dan Uli al-Albab dalam Alquran sebagai satu kesatuan dalam memberntuk kecerdasar suprarasional perspektif Jalaluddin dalam bukunya Psikologi Pendidikan Islam.

\footnotetext{
${ }^{2}$ Mochtar Buchori, Pendidikan Antisipatoris (Jakarta: Kanisius, 2001), h. 7.

${ }^{3}$ Wowo Sunaryo Kuswana, Biopsikologi: Pembelajaran Perilaku (Bandung: Alfabeta, 2014), h. 5-6.

${ }^{4}$ Koes Irianto, Anatomi dan Fisiologi (Bandung: Alfabeta, 2014), h. 446-449.

${ }^{5}$ Kuswana, Biopsikologi: Pembelajaran Perilaku, h. 7.

${ }^{6}$ Jalaluddin, Psikologi Pendidikan Islam, h. 308.

${ }^{7}$ Jalaluddin, h. 309.
}

Al Qalam: Jurnal Ilmiah Keagamaan dan Kemasyarakatan Vol. 14, No. 2, Juli-Desember 2020 
Muh. Haris Zubaidillah : Kecerdasaran Suprarasional: Konsep Uli al-Abshâr, Uli an-Nuhâ dan Uli al-Albâb dalam Alquran Perspektif Jalaluddin

\section{B. METODE PENELITIAN}

Metode yang digunakan dalam penelitian adalah penelitian kepustakaan (library research). Menurut Amir Hamzah, penelitian kepustakaan dapat digolongkan dalam pendekatan penelitian kualitatif, karena memiliki akar filosofis post-positivisme yang kuat. ${ }^{8}$ Sedangkan jenis penelitiannya adalah studi pemikiran tokoh.

Data yang diteliti pada penelitian ini adalah pandangan atau pemikiran Jalaluddin tentang konsep Uli al-Abshar, Uli an-Nuha dan Uli al-Albab dalam Alquran yang dimaknainya sebagai kecerdasar suprarasional. Sumber data utama adalah yang berjudul Psikologi Pendidikan Islam ditulis oleh Prof. Dr. Jalaluddin diterbitkan di Yogyakarta oleh Penerbit Pustaka Pelajar pada bulan Juli tahun 2018. ISBN 978602-229-928-8. Adapun sumber data utama adalah buku-buku atau literatur-literatur yang terkait dengan kajian pada artikel ini. Adapun teknik analisis yang digunakan adalah analisis isi (content analysis).

\section{HASIL DAN PEMBAHASAN}

1. Konsep Uli al-Abshar dalam Alquran

Konsep ini menurut Jalaluddin dapat dirujuk dalam tiga Surah dalam Alquran. Yakni dalam Q.S. Ali Imran/3: 13, Q.S. An-Nur/24: 44 dan Q.S. Al-Hasyr/59: 2.

Setelah memaparkan beberapa pendapat ahli tafsir terkait makna Uli al-Abshar, seperti menurut Ali Al-Shabuni, ${ }^{9}$ Abdullah Yusuf Ali $^{10}$ dan Sayyid Husain al-Thaba'thaba'i, ${ }^{11}$ Jalaluddin menyimpulkan bahwa indra penglihatan dan hati memiliki hubungan yang tak dapat dipisahkan. Menurutnya, secara garis besar Uli al-Abshar mengandung arti kemampuan manusia untuk melihat dengan menggunakan mata hati. Penglihatan yang bersifat batiniah. ${ }^{12}$

\section{Konsep Uli an-Nuha dalam Alquran}

Menurut Jalaluddin, konsep Uli an-Nuha dijumpai dua kali dalam Alquran. Yaitu Q.S. Thaha/20: 54 dan 128. Dalam kedua ayat tersebut, menurut Jalaluddin kata Uli an-Nuha dikaitkan dengan kemampuan akal untuk memahami tanda-tanda kemahakuasaan Allah baik dalam kehidupan hewan, hingga ke peristiwa dan peninggalan sejarah. ${ }^{13}$

Menurut beberapa ahli tafsir, Ali Al-Shabuni, ${ }^{14}$ Abdullah Yusuf Ali $^{15}$ dan Sayyid Husain alThaba'thaba' ${ }^{16}$ dapat disimpulkan bahwa Uli an-Nuha merujuk kepada orang-orang yang berakal sehat, bersih, memiliki moral dan nilai-nilai spiritual.

Hasan Langgulung menyatakan bahwa orang yang berakal memiliki empat tanda, yaitu penyayang, mencegah diri dari kebatilan, menanam harta di tempat yang benar dan mengetahui perbedaan antara teman dan musuh. ${ }^{17}$

\footnotetext{
${ }^{8}$ Lihat Amir Hamzah, Metode Penelitian Kepustakaan (Library Research) Kajian Filosofis, Teoretis, Aplikasi,
} Proses dan Hasil Penelitian (Batu: Literasi Nusantara, 2020), h. 8. Lihat juga Arief Furchan dan Agus Maimun, Studi tokoh: Metode Penelitian Mengenai Tokoh (Yogyakarta: Pustaka Pelajar, 2005), h. 10.

${ }^{9}$ Muhammad Ali Al-Shabuny, Shafwat at-Tafasir (Beirut: Dar al-Quran, 1980), h. 188.

10 Abdullah Yusuf Ali, The Holy Al-Qur'an: Text, Translation and Commentary (Maryland: Amana Corporation, 1981), h. 128.

${ }^{11}$ Sayyid Muhammad Husain Ath-Thaba'thaba'i, Al-Mizan fi at-Tafsir al-Qur'an (Beirut: Muassasah ilmi li alMathbu'at, 1991), h. 109.

${ }^{12}$ Jalaluddin, Psikologi Pendidikan Islam, h. 319.

${ }^{13}$ Jalaluddin, h. 320.

${ }^{14}$ Al-Shabuny, Shafwat at-Tafasir, h. 251.

${ }^{15}$ Ali, The Holy Al-Qur'an: Text, Translation and Commentary, h. 791.

${ }^{16}$ Ath-Thaba'thaba'i, Al-Mizan fi at-Tafsir al-Qur'an, h. 232.

Al Qalam: Jurnal Ilmiah Keagamaan dan Kemasyarakatan

Vol. 14, No. 2, Juli-Desember 2020 
Orang dengan karakter Uli an-Nuha telah melengkapi kepribadiannya dengan nilai-nilai yang positif. Selain itu, dalam memelihara nilai-nilai keimanannya, iapun harus berjuang menghadapi musuh-musuh dari luar dan sekaligus dari dalam dirinya. Kecerdasan dalam konsep Uli an-Nuha ternyata tidak semata-mata mengacu kepada kecerdasan otak. Di luar itu ada aspek-aspek lain yang mengiringi kecerdasan tersebut, yakni nilai-nilai yang bersifat spiritual dan moral. Dari komposisi yang demikian itu pula maka kecerdasan yang dihasilkan oleh otak yang bersih terbebaskan dari unsur-unsur spekulatif, karena kebenarannya terbimbing oleh tuntunan Allah. Selain itu juga terhindar dari kecenderungan manipulative karena Uli anNuha akal sudah didasarkan pada nilai-nilai imani. ${ }^{18}$

\section{Konsep Uli al-Albab dalam Alquran}

Konsep Uli al-Albab dicantumkan dalam Alquran sebanyak 15 kali pada 10 surah dalam Alquran dan mengacu ke berbagai konteks. Rangkaian penempatan dalam ayat-ayat Alquran tersebut akan menjelaskan konteks Uli al-Albab dengan segala karakteristiknya. Dengan memahami secara utuh konteksnya, Uli al-Albab bisa difahami karakteristik dan sifatnya dalam Alquran.

Dalam Q.S. Al-Baqarah/2: 179, konteksnya berhubungan dengan sikap takwa. Dalam Q.S. AlBaqarah/2: 269 Uli al-Albab dikaitkan dengan kemampuan memahami syariat agama dan Alquran. Karena kata "hikmah" dalam ayat tersebut dapat diartikan sebagai kemampuan memahami rahasia-rahasia syariat agama. Hikmah juga dapat diartikan sebagai pengetahuan amaliah dan amal ilmiah. ${ }^{19}$

Dalam Q.S. Ali Imran/3: 7 dan 190 yang menyatakan bahwa fenomena tersebut dalam ayat merupakan tanda-tanda tentang wujud dan kemahakuasaan Allah bagi Uli al-Albab, yakni orang-orang yang mempunyai akal dan jiwa yang tidak diselubungi oleh kerancuan. Merujuk pada Q.S. Ali Imran/3: 191, Uli al-Albab memiliki dua ciri pokok, yaitu tafakkud dan zikir. Keduanya menghasilkan natijah yang tersusun dalam pikiran hingga ke pengalaman dan pemanfaatannya dalam kehidpuan sehari-hari. ${ }^{20}$

Konsep Uli al-Albab berikutnya disebutkan pada Q.S. Al-Maidah/5: 100. Dalam ayat ini ciri-ciri Uli $a l$-Albab ditandai dengan orang-orang yang pikirannya tidak diselubungi oleh kerancuan, agar bertakwa sehingga dapat terhindar dari penyesalan dan siksa agar memperoleh keberuntungan. ${ }^{21}$

Dalam Q.S. Yusuf/12: 111, Uli al-Albab menurut Quraish Shihab adalah orang-orang yang berakal yang bersedia untuk beriman. Pada Q.S. Ar-Ra'd/13: 19 Uli al-Albab adalah orang-orang yang tidak dikotori pikirannya dengan kerancuan dan orang yang dapat menyadari perumpamaan dan pelajaran darinya. ${ }^{22}$

Dalam Q.S. Ibrahim/14: 52 dan Q.S. Shad/38: 43, Uli al-Albab dapat mengambil pelajaran dan tuntunan dari kandungan Alquran. Semuanya hanya dapat dipetik manfaatnya oleh orang-orang yang bersedia beriman. ${ }^{23}$

Pada Q.S. al-Zumar/39: 9 dan 18 juga pada Q.S. An-Nahl/40: 53-54 dan Q.S. Ath-Thalaq/65: 10, karakteristik Uli al-Albab adalah senantiasa terkait dengan nilai-nilai imani, serta kemampuan untuk

${ }^{17}$ Hasan Langgulung, Manusia dan Pendidikan: Suatu Analisis Psikologi dan Pendidikan (Jakarta: Al-Husna, 1986), h. 335.

${ }^{18}$ Jalaluddin, Psikologi Pendidikan Islam, h. 321.

19 M. Quraish Shihab, Al-Lubab: Makna, Tujuan dan Pelajaran dari Surah-Surah Al-Qur'an (Tangerang: Lentera Hati, 2012), h. 88.

${ }^{20}$ M. Quraish Shihab, Wawasan Al-Qur'an: Tafsir Maudhu'i atas Pelbagai Persoalan Umat (Bandung: Mizan, 1996), h. 443.

${ }^{21}$ Shihab, Al-Lubab: Makna, Tujuan dan Pelajaran dari Surah-Surah Al-Qur'an, h. 299.

${ }^{22}$ Shihab, h. 53-54.

${ }^{23}$ Shihab, h. 54.

Al Qalam: Jurnal Ilmiah Keagamaan dan Kemasyarakatan

Vol. 14, No. 2, Juli-Desember 2020 
memahami segala bentuk perumpamaan yang ditampilkan Allah SWT pada sejarah, kemahaagungan-Nya dan ayat-ayat yang mengindikasikan kemahakuasaan Allah. ${ }^{24}$

\section{Karakteristik Ulul Albab}

Pada rangkaian ayat-ayat Alquran di atas, Menurut Jalaluddin Ulul Albab dapat dimaknakan sebagai orang yang berakal sehat disertai dengan hati yang bersih, selalu dikaitkan dengan nilai-nilai spiritual yang bersumber dari fitrah. ${ }^{25}$ Di antara ciri-ciri dan karakteristik Ulul Albab menurut Jalaluddin adalah:

a. Senantiasa mengerjakan kebaikan sebagai bekal takwa.

b. Memperoleh hikmah dari Allah berupa pengetahuan amaliah dan amal ilmiah.

c. Memiliki kedalaman ilmu dan iman.

d. Mengagungkan kemahakuasaan Allah terhadap penciptaan alam semesta, dengan selalu bertafakkur dan zikir di berbagai kondisi: duduk, berdiri dan berbaring.

e. Tidak tergoda oleh keburukan walaupun menarik.

f. Beriman kepada segala kebenaran penjelasan Alquran.

g. Mampu menghayati keberkatan Alquran dan rahmat Allah.

h. Tekun dalam melaksanakan ibadah malam hari, karena takut akan azab akhirat sambil mengharap rahmat Allah.

i. Mampu membedakan antara orang yang berilmu dan tidak berilmu.

j. Memiliki kemampuan untuk memahami petunjuk dan peringatan yang terkandung dalam kitab suci.

k. Beriman dan bertakwa kepada Allah.

1. Selalu memenuhi janji kepada siapa saja.

m. Menghubungkan hubungan yang diperintahkan Allah seperti silaturrahim dan mensinkronkan antara ucapan dan perbuatan.

n. Takut kepada Allah dan Hari Hisab.

o. Sabar melaksanakan perintah, menjauhi larangan, serta menghadapi tantangan dan petaka.

p. Melaksanakan shalat secara baik dan berkesinambungan.

q. Menafkahkan sebagian rezeki, baik secara sembunyi atau terang-terangan.

r. Menyingkap dengan baik dampak yang terjadi atau akan terjadi dari suatu keburukan. ${ }^{26}$

M. Dawam Raharjo sebagaimana dikutip oleh Komaruddin Hidayat melihat setidaknya ada tiga dimensi ciri-ciri Ulul Albab. Pertama, dimensi ontologis. Dalam dimensi ini manusia telah menarik jarak dari alam dan semua yang ada, termasuk dirinya sendiri, masyarakat, dan sejarah, lalu menjadikannya sebagai objek pengamatan rasional. Kedua, dimensi fungsional yang bertolak dari pengertian bahwa alam semesta diciptakan Allah dengan tujuan, serta juga merupakan sesuatu yang haq bukan yang bathil. Ketiga, dimensi aksiologis atau etis, yang melihat sesuatu dari segi buruk atau baik, benar atau salah. ${ }^{27}$

Menurut Jalaluddin, kecerdasan yang hakiki adalah kecerdasan hati, yaitu tingkat kemampuan memahami. Karena tinggi rendahnya nilai-nilai kemanusiaan ditentukan oleh tingkat kemampuan memahami ayat-ayat Allah. Aparat tubuh yang mampu memahami ayat-ayat Allah adalah qalb (hati), bukan otak yang dikonotasikan dengan kecerdasan intelektual. ${ }^{28}$

Berdasarkan dari penjelasan tentang pengertian dari beberapa ahli, Jalaluddin menyimpulkan bahwa intelegensi memiliki keterbatasan. Intelegensi hanya terbatas pada pengukuran hasil belajar yang

\footnotetext{
${ }^{24}$ Shihab, h. 110.

${ }^{25}$ Jalaluddin, Psikologi Pendidikan Islam, h. 326.

${ }^{26}$ Shihab, Al-Lubab: Makna, Tujuan dan Pelajaran dari Surah-Surah Al-Qur'an, h. 69-70.

${ }^{27}$ Komaruddin Hidayat, Agama di Tengah Kemelut (Jakarta: Mediacita, 2001), h. 362.

${ }^{28}$ Jalaluddin, Psikologi Pendidikan Islam, h. 304-305.
}

Al Qalam: Jurnal Ilmiah Keagamaan dan Kemasyarakatan Vol. 14, No. 2, Juli-Desember 2020 
menyangkut potensi otak manusia. Sehingga lebih tepatnya intelegensi lebih mengacu kepada psikologi belajar dari pada psikologi pendidikan. Sebab, mengacu kepada maknanya, aktivitas pendidikan mencakup upaya sadar untuk meningkatkan dan mengembangkan seluruh potensi yang dimiliki manusia, baik fisik, mental maupun spiritual. ${ }^{29}$

Pendidikan merupakan serangkaian proses. Mendidik menurut salah satu definisi adalah pertolongan yang diberikan oleh siapa yang bertanggung jawab atas pertumbuhan seseorang yang membawanya ke tingkat dewasa. Pendidikan bukan sesuatu yang instan. Menuju tingkat kedewasaan diperlukan sebuah proses panjang.

Saat ini, ada semacam kecenderungan umum yang dalam menilai kemampuan peserta didik, yaitu kecerdasan. Konsekwensinya adalah terbelahnya peserta didik menjadi anak pandai dan anak bodoh. Anak yang dengan tingkat kecerdasan tinggi disebut anak pandai. Sementara anak dengan kecerdasan rendah digolongkan anak bodoh. ${ }^{30}$ Dalam skala Intelegence Quotient (IQ), anak yang biasa memiliki IQ = 100, anak yang cerdas memiliki IQ $=125$, sementara anak yang ber-IQ 75 tergolong bodoh. ${ }^{31}$ Mengenai klasifikasi skor IQ ini, ada beberapa teori yang memberikan rincian lebih detail, seperti menurut Gaus dan StanfordBinet. $^{32}$

Menurut Jalaluddin, skor intelektual di atas tidak bisa menjadi ukuran keberhasilan anak. Ada anak yang dengan kecerdasan belajarnya kurang, namun kecerdasan untuk kehidupan tinggi. Dalam kehidupan praktis mereka sangat terampil dan cekatan, sementara ketika duduk di bangku belajar dianggap bodoh. Hal itu disebabkan karena biasanya tempo belajarnya lambat. Padahal keterlambatan tersebut disebabkan karena anak tersebut mempunyai sifat teliti. Anak yang teliti cenderung lambat dalam mencerna dan memahami pelajaran, sehingga ia banyak mengalami ketertinggalan dalam belajar. Atas dasar itu, anak tersebut dikonotasikan sebagai anak bodoh. Gejala kebodohan menurut Jalaluddin ada yang bersifat sementara. Seorang anak dianggap bodoh pada tingkat-tingkat awal. Namun, beberapa tahun berikutnya, tingkat perkembangannya meningkat dengan cepat, sehingga ia menjadi murid yang baik.

Pada akhirnya, gejala seperti ini hendaknya dihadapi dengan bijaksana, agar peserta didik tidak menjadi korban kekeliruan dalam menilai dan mengambil kesimpulan. Pendidikan diarahkan kepada pemberian bimbingan ke aktivitas dan pembiasaan yang bersifat positif, sesuai dengan kemampuan dan potensi yang dimilikinya secara menyeluruh. Bukan semata-mata hanya diarahkan pada aspek kognitif yang cenderung hanya membedakan "anak pintar" dan "anak bodoh". ${ }^{33}$

Tingkat kecerdasan seseorang tidak ditentukan oleh kemampuan kerja otak semata. Menurut Jalaluddin, penilaian seperti ini tidak bijaksana. Sebab aspek yang dinilai hanya mengacu kepada kemampuan intelektual semata. Hanya pada aspek yang berkaitan dengan kemampuan otak yang terbatas. Sementara dalam kajian psikologi sendiri kecerdasan itu beragam. Misalnya teori Multiple Intellegences memperkenalkan gagasan kecerdasan yang lebih majemuk. ${ }^{34}$

Howard Gardner dalam bukunya Frame of Mind: The Theory of Multiple Intellegences (1993) membagi kecerdasan menjadi sepuluh. 1) kecerdasan bahasa (linguistic); 2) kecerdasan logika (matematika); 3) kecerdasan kinestetik (olahraga); 4) kecerdasan musical; 5) kecerdasan antarpersonal (pergaulan); 6) kecerdasan interpersonal (memahami perasaan orang dan diri); 7) kecerdasan spasial (memahami ruangan);

\section{${ }^{29}$ Jalaluddin, h. 307.}

${ }^{30}$ Crijns dan Reksosiwwojo, Pengantar di dalam Praktik Pengadjaran dan Pendidikan (Djakarta: NoordhoffKolff, 1964), h. 283.

${ }^{31}$ Buchori, Pendidikan Antisipatoris, h. 61.

${ }^{32}$ Kuswana, Biopsikologi: Pembelajaran Perilaku, h. 192-194.

${ }^{33}$ Jalaluddin, Psikologi Pendidikan Islam, h. 311.

${ }^{34}$ Kuswana, Biopsikologi: Pembelajaran Perilaku, h. 241.

Al Qalam: Jurnal Ilmiah Keagamaan dan Kemasyarakatan Vol. 14, No. 2, Juli-Desember 2020 
8) kecerdasan spiritual; 9) kecerdasan naturalis (lingkungan); dan 10) kecerdasan eksistensial. Kajian Howard Gardner ini menunjukkan bahwa tingkat kecerdasan manusia sebenarnya tidak hanya dilambangkan oleh tingkat kemampuan otak atau pada aspek kognitif semata. ${ }^{35}$

Menurut Bergson dan pengikutnya, akal memang kompeten untuk menganalisis ruang, tetapi tidak tentang waktu. Akal sangat kompeten untuk memahami "pengalaman fenomenal", tetapi tidak dengan memahami "pengalaman ekstensial". Dengan demikian kemampuan akal memiliki keterbatasan. Akal hanya mampu mengidentifikasi hal-hal yang bersifat indrawi dan pengetahuan saja. Padahal tugas penting pendidikan adalah membentuk citarasa pada anak terkait nilai-nilai luhur dalam hidup. ${ }^{36}$

Kesadaran akan nilai-nilai luhur ini tampaknya ikut memberi pengaruh dalam kajian psikologi modern. Di mana setelah Perang Dunia Kedua, spiritualitas dan agama menjadi terputus dan muncul kembali setelah dibangkitkan oleh aliran psikologi humanistik. Spiritualitas oleh beberapa ahli psikologi tampaknya mulai dikaitkan dengan kecerdasan. Danah Zohar dan Marshall misalnya, mereka memunculkan istilah kecerdasan spiritual. Mereka menyatakan "sementara computer memiliki IQ dan hewan memiliki EQ, maka pada hakikatnya dengan adanya SQ menjadikan manusia berbeda dan terpisah". Di mana kecerdasan spiritual merupakan kecerdasan jiwa, kecerdasan diri yang mendalam. ${ }^{37}$

Tingkat kecerdasan spiritual berbeda dari IQ dan EQ. IQ dapat memecahkan masalah logis. EQ memungkinkan seseorang untuk menilai situasi dan perilaku sesuai dengan keseimbangan emosi. Sementara SQ bertanya apakah ini layak berada di situasi itu sebelum terlibat di dalamnya. SQ memiliki hubungan dengan agama formal. Para ahlinya menilai bahwa kecerdasan spiritual merupakan kecerdasan tertinggi manusia, sebagai kecerdasan untuk memecahkan masalah pada nilai-nilai. Kecerdasan spiritual merupakan kemampuan menemukan makna dan tujuan hidup, memahami dan memelihara hubungan dengan Tuhan, menentukan dan mengikuti jalan moral etika dan praktik cinta kasih. Spiritualitas mengacu kepada makna, nilai dan transendensi. ${ }^{38}$

Memang kecerdasan spiritual menurut Jalaluddin pada awalnya tidak secara eksplisit mengacu kepada agama. Namun tampaknya kecerdasan spiritual tidak mungkin bisa terlepas dari nilai-nilai ajaran agama. Fakta menunjukkan, bahwa kajian psikologi humanistic termasuk di dalamnya kajian kecerdasan spiritual telah memasuki ranah agama. Psikologi humanistik berupaya menjelajahi nilai-nilai spiritual yang bersinggungan dengan agama yang dianut manusia, walaupun hasil kajian tersebut masih belum menyentuh nilai hakiki agama yang menyatu dalam fitrah manusia sebagai ciptaan Allah.

Menurut Jalaluddin, peran agama tidak dapat dipisahkan dalam kehidupan manusia. Ia mengutip William James yang menegaskan bahwa selama manusia masih memiliki naluri cemas dan mengharap, selama itu pula ia beragama (berhubungan dengan Tuhan). Itulah sebabnya mengapa perasaan takut merupakan salah satu dorongan terbesar untuk beragama. ${ }^{39}$

Dalam kajian berikutnya, ahli psikologi saraf berhasil menguak eksistensi God-Spot dalam otak manusia yang merupakan "tabir rahasia" yang mengungkapkan hubungan manusia dengan Tuhan. Lagi-lagi terungkap bagaimana hubungan antara God-Spot dengan nilai-nilai agama.

Sistem nilai dalam manusia menurut Meredith B. Mc. Guire dibentuk melalui proses belajar dan sosialisasi. Perangkat ini dipengaruhi oleh keluarga, teman, institusi pendidikan dan masyarakat luas.

${ }^{35}$ Jalaluddin, Psikologi Pendidikan Islam, h. 313.

${ }^{36}$ Buchori, Pendidikan Antisipatoris, h. 127.

${ }^{37}$ Ary Ginandjar Agustian, ESQ Emotional Spiritual Quotient: Rahasia Sukses Membangun Kecerdasan Emosi dan Spiritual Berdasarkan 6 Rukun Iman dan 5 Rukun Islam (Jakarta: Arga, 2001), h. 26-27.

${ }^{38}$ Kuswana, Biopsikologi: Pembelajaran Perilaku, h. 266-267.

39 Jalaluddin, Psikologi Pendidikan Islam, h. 314; Lihat juga Shihab, Wawasan Al-Qur'an: Tafsir Maudhu'i atas Pelbagai Persoalan Umat, h. 376.

Al Qalam: Jurnal Ilmiah Keagamaan dan Kemasyarakatan

Vol. 14, No. 2, Juli-Desember 2020 
Berdasarkan perangkat informasi yang diperoleh seseorang dari hasil belajar dan sosialisasi tadi menyatu dalam membentuk identitas seseorang. ${ }^{40}$

Dalam konsep pendidikan Islam, proses pembentukan sistem nilai tersebut berawal dari lingkungan keluarga dan diawali sejak bayi dilahirkan, yakni melalui azan. Azan diperdengarkan sejak awal dimaksudkan nilai-nilai kebesaran Tuhan, syahadat islam bersama perintah shalat menjadi kalimat pertama yang masuk ke telinganya. Anak yang sejak awal kehidupannya sudah ditanamkan nilai-nilai tauhid yang lurus sebagai pangkal ajaran Islam, insya Allah kelak waktu ia tumbuh dewasa akan lebih mudah diarahkan ke jalan yang lurus. ${ }^{41}$ Fenomena ini setidaknya memberikan pamahaman bahwa hubungan antara kecerdasan dengan nilai-nilai agama perlu dibentuk sejak usia dini. Berbagai hasil kajian dan penelitian mendukung pernyataan ini. ${ }^{42}$

Agama yang diwahyukan Tuhan, benihnya muncul dari pengenalan dan pengalaman manusia di muka bumi. Di sini ia menemukan tiga hal, yaitu keindahan, kebenaran dan kebaikan. Selanjutnya ketiga hal tersebut digabungkan dalam satu kata yaitu "suci". Mencari kebenaran menghasilkan ilmu, mencari kebaikan menghasilkan akhlak dan mencari keindahan menghasilkan seni. ${ }^{43}$

Ketiga aspek ini sama sekali tidak dapat dilepaskan dari kehidupan manusia. Oleh karenanya, dalam pendidikan Islam, secara psikologis pembentukan nilai-nilai suci itu sudah harus dilakukan sejak dini. Salah satunya dengan memperdengarkan azan di telinganya. Proses penanaman nilai tauhid yang suci sejak awal akan sangat mempengaruhi terhadap produk akal manusia. Proses tersebut akan menghasilkan akal cerdas dan suci. Sinergitas keduanya akan berpengaruh kuat terhadap pembentukan kecerdasan suprarasional. ${ }^{44}$

Dalam Alquran konsep kecerdasan manusia selalu dikaitkan dengan nilai-nilai spiritual yang bersumber dari nilai kesucian fitrah yang ada dalam diri manusia. Menurut Jalaluddin, informasi Alquran yang mengacu kepada kecerdasan ini terkandung dalam tiga konsep utama, yakni: Uli al-Abshar, Uli anNuha dan Uli al-Albab. Ketiganya dapat dimaknai sebagai orang yang berakal sehat disertai dengan hati yang bersih, selalu dikaitkan dengan nilai-nilai spiritual yang bersumber dari fitrah.

\section{KESIMPULAN}

Berdasarkan paparan di atas, dapat disimpulkan bagaimana konsep kecerdasan perspektif Jalaluddin. Menurutnya, kecerdasan yang hakiki adalah kecerdasan hati, yaitu tingkat kemampuan memahami. Karena tinggi rendahnya nilai-nilai kemanusiaan ditentukan oleh tingkat kemampuan memahami ayat-ayat Allah. Aparat tubuh yang mampu memahami ayat-ayat Allah adalah qalb (hati), bukan otak yang dikonotasikan dengan kecerdasan intelektual.

Agama yang diwahyukan Tuhan, benihnya muncul dari pengenalan dan pengalaman manusia di muka bumi. Di sini ia menemukan tiga hal, yaitu keindahan, kebenaran dan kebaikan. Selanjutnya ketiga hal tersebut digabungkan dalam satu kata yaitu "suci". Mencari kebenaran menghasilkan ilmu, mencari kebaikan menghasilkan akhlak dan mencari keindahan menghasilkan seni.

Ketiga aspek ini sama sekali tidak dapat dilepaskan dari kehidupan manusia. Oleh karenanya, dalam pendidikan Islam, secara psikologis pembentukan nilai-nilai suci itu sudah harus dilakukan sejak dini. Salah satunya dengan memperdengarkan azan di telinganya. Proses penanaman nilai tauhid yang suci sejak awal

\footnotetext{
${ }^{40}$ Jalaluddin, Psikologi Pendidikan Islam, h. 315.

41 Adnan Hasan Shalih Baharits, Mendidik Anak Laki-Laki, trans. oleh Syihabuddin (Jakarta: Gema Insani,

${ }^{42}$ Linda L. Davidoff, Introduction of Psychology (New York: McGraw-Hill Book Company, 1987), h. 66.

${ }^{43}$ Shihab, Wawasan Al-Qur'an: Tafsir Maudhu'i atas Pelbagai Persoalan Umat, h. 377-378.

${ }^{44}$ Jalaluddin, Psikologi Pendidikan Islam, h. 317.
} 2008), h. 29.

Al Qalam: Jurnal Ilmiah Keagamaan dan Kemasyarakatan Vol. 14, No. 2, Juli-Desember 2020 
Muh. Haris Zubaidillah : Kecerdasaran Suprarasional: Konsep Uli al-Abshâr, Uli an-Nuhâ dan Uli al-Albâb dalam Alquran Perspektif Jalaluddin

akan sangat mempengaruhi terhadap produk akal manusia. Proses tersebut akan menghasilkan akal cerdas dan suci. Sinergitas keduanya akan berpengaruh kuat terhadap pembentukan kecerdasan suprarasional.

Dalam Alquran konsep kecerdasan manusia selalu dikaitkan dengan nilai-nilai spiritual yang bersumber dari nilai kesucian fitrah yang ada dalam diri manusia. Menurut Jalaluddin, informasi Alquran yang mengacu kepada kecerdasan ini terkandung dalam tiga konsep utama, yakni: Uli al-Abshar, Uli anNuha dan Uli al-Albab. Ketiganya dapat dimaknai sebagai orang yang berakal sehat disertai dengan hati yang bersih, selalu dikaitkan dengan nilai-nilai spiritual yang bersumber dari fitrah.

\section{DAFTAR PUSTAKA}

Agustian, Ary Ginandjar. ESQ Emotional Spiritual Quotient: Rahasia Sukses Membangun Kecerdasan Emosi dan Spiritual Berdasarkan 6 Rukun Iman dan 5 Rukun Islam. Jakarta: Arga, 2001.

Ali, Abdullah Yusuf. The Holy Al-Qur'an: Text, Translation and Commentary. Maryland: Amana Corporation, 1981.

Al-Shabuny, Muhammad Ali. Shafwat at-Tafasir. Beirut: Dar al-Quran, 1980.

Ath-Thaba'thaba'i, Sayyid Muhammad Husain. Al-Mizan fi at-Tafsir al-Qur'an. Beirut: Muassasah ilmi li al-Mathbu'at, 1991.

Baharits, Adnan Hasan Shalih. Mendidik Anak Laki-Laki. Diterjemahkan oleh Syihabuddin. Jakarta: Gema Insani, 2008.

Buchori, Mochtar. Pendidikan Antisipatoris. Jakarta: Kanisius, 2001.

Crijns, dan Reksosiwwojo. Pengantar di dalam Praktik Pengadjaran dan Pendidikan. Djakarta: NoordhoffKolff, 1964.

Davidoff, Linda L. Introduction of Psychology. New York: McGraw-Hill Book Company, 1987.

Furchan, Arief, dan Agus Maimun. Studi tokoh: Metode Penelitian Mengenai Tokoh. Yogyakarta: Pustaka Pelajar, 2005.

Hamzah, Amir. Metode Penelitian Kepustakaan (Library Research) Kajian Filosofis, Teoretis, Aplikasi, Proses dan Hasil Penelitian. Batu: Literasi Nusantara, 2020.

Hidayat, Komaruddin. Agama di Tengah Kemelut. Jakarta: Mediacita, 2001.

Irianto, Koes. Anatomi dan Fisiologi. Bandung: Alfabeta, 2014.

Jalaluddin. Psikologi Pendidikan Islam. Yogyakarta: Pustaka Pelajar, 2018.

Kuswana, Wowo Sunaryo. Biopsikologi: Pembelajaran Perilaku. Bandung: Alfabeta, 2014.

Langgulung, Hasan. Manusia dan Pendidikan: Suatu Analisis Psikologi dan Pendidikan. Jakarta: Al-Husna, 1986.

Shihab, M. Quraish. Al-Lubab: Makna, Tujuan dan Pelajaran dari Surah-Surah Al-Qur'an. Tangerang: Lentera Hati, 2012.

Wawasan Al-Qur'an: Tafsir Maudhu'i atas Pelbagai Persoalan Umat. Bandung: Mizan, 1996.

Al Qalam: Jurnal Ilmiah Keagamaan dan Kemasyarakatan

Vol. 14, No. 2, Juli-Desember 2020 